\title{
Optimization of an electrochemical cell with an adsorption layer for NOx removal
}

\author{
Shao, Jing; Kammer Hansen, Kent
}

Published in:

Journal of Solid State Electrochemistry

Link to article, DOI:

10.1007/s10008-012-1778-4

Publication date:

2012

Link back to DTU Orbit

\section{Citation (APA):}

Shao, J., \& Kammer Hansen, K. (2012). Optimization of an electrochemical cell with an adsorption layer for $\mathrm{NO}_{\mathrm{x}}$ removal. Journal of Solid State Electrochemistry, 16, 3331-3340. https://doi.org/10.1007/s10008-012-1778-4 x

\section{General rights}

Copyright and moral rights for the publications made accessible in the public portal are retained by the authors and/or other copyright owners and it is a condition of accessing publications that users recognise and abide by the legal requirements associated with these rights.

- Users may download and print one copy of any publication from the public portal for the purpose of private study or research.

- You may not further distribute the material or use it for any profit-making activity or commercial gain

- You may freely distribute the URL identifying the publication in the public portal

If you believe that this document breaches copyright please contact us providing details, and we will remove access to the work immediately and investigate your claim. 


\title{
Optimization of an electrochemical cell with an adsorption layer for $\mathrm{NO}_{\mathrm{x}}$ removal
}

\author{
Jing Shao ${ }^{*}$ and Kent Kammer Hansen \\ Department of Energy Conversion and Storage \\ Technical University of Denmark (DTU), DK-4000 Roskilde, Denmark
}

\begin{abstract}
The structure of a multilayer electrochemical cell with an adsorption layer was optimized by removing a yttria-stabilized zirconia cover layer. It was found that the $\mathrm{NO}_{x}$ removal properties of the electrochemical cell were dramatically enhanced through the optimization, especially under conditions of low voltage, intermediate temperature and high $\mathrm{O}_{2}$ concentration. The pronounced increase in activity and selectivity for $\mathrm{NO}_{\mathrm{x}}$ decomposition after removing the ytrria-stabilized zirconia cover layer was attributed to the extensive release of selective reaction sites for $\mathrm{NO}_{x}$ species and a strong promotion for $\mathrm{NO}_{x}$ reduction from the interaction of the directly connected adsorption layer with both the Pt and catalytic layers. The optimized electrochemical cell may provide a promising solution for $\mathrm{NO}_{\mathrm{x}}$ emission control.
\end{abstract}

Key words: $\mathrm{NO}_{\mathrm{x}}$ removal, Electrochemical cell, Optimization, $\mathrm{NO}_{\mathrm{x}}$ adsorption

\footnotetext{
*E-mail: jish@risoe.dtu.dk
} 


\section{Introduction}

Lean burn engines can greatly improve fuel economy, however, the amount of $\mathrm{NO}_{\mathrm{x}}$ emission also increases under lean conditions and cannot be removed by the traditional three-way catalyst due to the $\mathrm{O}_{2}$ rich environment [1]. $\mathrm{NO}_{\mathrm{x}}$ is dangerous for both human beings and the environment, causing heath problems [2], acid rain and depletion of the protective ozone layer [3, 4]. Government regulations to limit $\mathrm{NO}_{\mathrm{x}}$ emission are becoming increasingly more stringent in many countries $[5,6]$. Therefore, there is high demand to find an effective method to reduce $\mathrm{NO}_{\mathrm{x}}$ emission from lean burn engine exhaust. The electrochemical reduction of $\mathrm{NO}_{\mathrm{x}}$ using a solid oxide cell is an attractive technique for lean burn exhaustgas after treatment because it requires no additional reducing agents other than electrons and has the potential to form only $\mathrm{N}_{2}$ and $\mathrm{O}_{2}[7,8]$. The challenge of this technique is to achieve both high selectivity and activity towards $\mathrm{NO}_{x}$ reduction in the presence of excess $\mathrm{O}_{2}$. Thus a lot of research effort has been made on searching suitable electrode materials and optimizing the cell structure $[7,8]$.

Recently, K. Hamamoto et al. proposed a new type of electrochemical cell with a multilayer cathode and a $\mathrm{NO}_{\mathrm{x}}$ adsorption layer or a $\mathrm{NO}_{\mathrm{x}}$ adsorbent for the $\mathrm{NO}_{\mathrm{x}}$ removal [9-11]. It was reported that the introduction of a $\mathrm{NO}_{x}$ adsorption layer greatly improved both the activity and selectivity of the electrochemical cell towards $\mathrm{NO}_{\mathrm{x}}$ reduction $[9,10]$. Figure 1 shows a sketch of such a cell with an adsorption layer for $\mathrm{NO}_{\mathrm{x}}$ decomposition [9]. During the cell operation, the external voltage was applied between the mesh-patterned Pt cathode and the Pt|YSZ (yttria stabilized zirconia) anode, which led to the polarization of the YSZ electrolyte and the reduction of $\mathrm{NiO}$ to nano $\mathrm{Ni}$ grains in the vicinity of $\mathrm{NiO}$ YSZ interfacial regions in the catalytic layer [8, 9, 12-15]. Because the adsorption and decomposition of $\mathrm{NO}_{\mathrm{x}}$ molecules occurs in preference to oxygen molecules on Ni grain surfaces [16-19], the self-assembled nano-pores and nano-Ni particles in the catalytic layer provide a highly selective reaction site for $\mathrm{NO}_{\mathrm{x}}$ reduction $[8,9,12-15]$ and also suppress the unwanted reaction of oxygen 
decomposition [20,21]. The adsorption layer, coated on the cathode side of the electrochemical cell, was made of a traditional NSR ( $\mathrm{NO}_{\mathrm{x}}$ storage and reduction) catalyst that is normally used to trap and reduce $\mathrm{NO}_{x}$ through a cyclic switch between lean and rich conditions [22]. It was previously proposed [9] that an additional adsorption layer could provide a $\mathrm{NO}_{\mathrm{x}}$-rich atmosphere to the reaction sites in the $\mathrm{NiO}$ YSZ catalytic layer to promote $\mathrm{NO}_{\mathrm{x}}$ reduction. A YSZ cover layer was deposited on the top of the catalytic layer in order to increase the $\mathrm{NO}_{\mathrm{x}}$ selectivity, because it was stated that the YSZ upper layer led to inhibit the $\mathrm{O}_{2}$ decomposition on the open surface of the catalytic layer and increase the amount of nano-Ni grains in the interface region of YSZ|NiO $[8,12,13]$.

However, for the electrochemical cell itself, the cathode with a YSZ cover layer was developed before the adsorption layer has been introduced $[8,12-15,20,21]$. Although on a cell without the adsorption layer, the deposition of a YSZ upper layer led to improve $\mathrm{NO}_{\mathrm{x}}$ selectivity $[8,12,13]$, after adding the adsorption layer, we believe the presence of the YSZ cover layer will be harmful to $\mathrm{NO}_{\mathrm{x}}$ decomposition. First, the diffusion of $\mathrm{NO}_{x}$ gas from the adsorption layer to the reaction sites in the catalytic layer should be severely impeded by the intervening YSZ layer, which could in turn inhibit the desorption of the $\mathrm{NO}_{\mathrm{x}}$ stored in the adsorption layer. Second, a promotion effect for $\mathrm{NO}_{\mathrm{x}}$ removal may be generated at the interface of the adsorption layer and the Pt layer or catalytic layer because the adsorption and desorption properties of the $\mathrm{NO}_{x}$ adsorbent in the vicinity of the reaction site may play an important role in $\mathrm{NO}_{\mathrm{x}}$ decomposition $[9,10]$. But this positive effect cannot be utilized with the YSZ cover layer because it blocks the direct contact between the adsorption layer and the other layers. Therefore, in this study, we modified the structure of the electrochemical cell by removing the YSZ cover layer to make the cell better cooperate with the adsorption layer.

\section{Experiment}

\subsection{Cell preparation}


A schematic diagram of the electrochemical cell with a YSZ cover layer can be found in figure 1. The cell was supported on a $200-\mu \mathrm{m}$ layer of $\mathrm{YSZ}\left(8 \% \mathrm{Y}_{2} \mathrm{O}_{3}\right.$ doped $\left.\mathrm{ZrO}_{2}\right)$ electrolyte with a multilayer cathode and a Pt|YSZ anode. An adsorption layer was applied to the surface of the cathode. Here, two kinds of electrochemical cells were prepared and tested for comparison: one with a YSZ cover layer, named S1; the other one without a YSZ cover layer, named S2. Other than the YSZ cover layer, all the other parts of these two cells were fabricated in the same way. The preparation procedure of S1 is described below as an example.

The catalytic layer was made by screen printing a composite paste of 55 mol\% NiO - 45 mol\% YSZ (8\% $\mathrm{Y}_{2} \mathrm{O}_{3}$ doped $\mathrm{ZrO}_{2}$ ) on a $5 \mathrm{~cm} \times 5 \mathrm{~cm}$ YSZ tape. Then, the NiOlYSZ layer was sintered at $1450{ }^{\circ} \mathrm{C}$ for 5 hours. A net-shaped Pt layer was screen printed over the NiO|YSZ layer and calcined at $1250^{\circ} \mathrm{C}$ for 1 hour. A $\mathrm{YSZ}\left(8 \% \mathrm{Y}_{2} \mathrm{O}_{3}\right.$ doped $\mathrm{ZrO}_{2}$ ) cover layer was later screen printed over the Pt layer and sintered at $1450{ }^{\circ} \mathrm{C}$ for 3 hours. The Pt|YSZ paste (TR-7070, Tanaka Kikinzoku) was subsequently screen printed on the other side of the YSZ tape and sintered at $1400{ }^{\circ} \mathrm{C}$ for 1 hour. Finally, the adsorption layer was coated by dripping several drops of an adsorbent solution on the top YSZ cover layer. The adsorbent solution was made by mixing $10 \mathrm{wt} \%$ adsorbent and $10 \mathrm{wt} \%$ Pluronic 123 surfactant (BASF) in water. The adsorbent was composed of $10 \mathrm{wt} \% \mathrm{~K}$ and $3 \mathrm{wt} \% \mathrm{Pt}$ supported on $\mathrm{Al}_{2} \mathrm{O}_{3}$ powder. The adsorption layer was first dried at $110{ }^{\circ} \mathrm{C}$ for 12 hours, followed by heating at $600{ }^{\circ} \mathrm{C}$ for 1 hour. The preparation was similar to that of Hamamoto et al [9]. After the preparation, the large cell $(5 \mathrm{~cm} \times 5 \mathrm{~cm})$ was laser-cut into several small round cells with diameters of $14 \mathrm{~mm}$.

\subsection{Electrochemical test}

For the electrochemical test, S1 and S2 were examined under the same conditions. The cells were set in a quartz tube reactor [23] inside a furnace and connected to a Gamry Reference 600 potentiostat. The cells were polarized under -1.5 to $-4.5 \mathrm{~V}$ for a certain period in the temperature range of $375^{\circ} \mathrm{C}$ to 
$500{ }^{\circ} \mathrm{C}$, with $25^{\circ} \mathrm{C}$ intervals. The gas composition was $1000 \mathrm{ppm} \mathrm{NO}$ and $0 \%-8 \% \mathrm{O}_{2}$ in a balance gas of $\mathrm{Ar}$ with a flow rate of $2 \mathrm{~L} / \mathrm{h}$, maintained by Brooks mass flow controllers. The outlet gas composition was monitored throughout the test. The $\mathrm{NO}, \mathrm{NO}_{2}$ and $\mathrm{NO}_{\mathrm{x}}$ concentration were measured by chemiluminescence (Model 42i HL, Thermo Scientific). The $\mathrm{N}_{2}$ and $\mathrm{N}_{2} \mathrm{O}$ were measured by mass spectrometry (Omnistar GSD 301, Pfeiffer Vacuum). No $\mathrm{N}_{2} \mathrm{O}$ was detected in all the tests.

\subsection{Microstructure characterization}

The microstructure and element composition of the cells before and after the test were investigated by scanning electron microscopy (Zeiss Supra 35) and EDS (energy dispersive spectroscopy). The cells were broken manually and the cross section was polished and coated with carbon. In order to distinguish different elements on the cross section, all the images were recorded with the backscattered detector.

\section{Results}

The performance of the electrochemical cell can be evaluated by its activity and selectivity toward $\mathrm{NO}_{\mathrm{x}}$ reduction. The activity of the cell can be represented by the $\mathrm{NO}_{x}$ conversion rate, a percentage of the $\mathrm{NO}_{\mathrm{x}}$ decomposed compared with the total $\mathrm{NO}_{\mathrm{x}}$ content. The selectivity can be evaluated by current efficiency $(\mathrm{CE})$, a ratio of the current consumed by $\mathrm{NO}_{\mathrm{x}}$ reduction $\left(I_{\mathrm{NO}}\right)$ to the total current $\left(I_{\text {tot }}\right)$ flowing through the cell. $I_{\text {NO }}$ is calculated using Faraday's law, as shown in equation 1 . The current consumed by $\mathrm{O}_{2}$ reduction is calculated by subtracting $I_{\mathrm{NO}}$ from $I_{\text {tot }}$.

$\Delta \mathrm{NO}_{\mathrm{x}}$ is the amount of $\mathrm{NO}_{\mathrm{x}}$ decomposition; $z$ is the charge change of $\mathrm{N}$ from $\mathrm{NO}_{\mathrm{x}}$ to $\mathrm{N}_{2}$ (for $\mathrm{NO}, z=2$; for $\left.\mathrm{NO}_{2}, z=4\right) ; v$ is the total flow rate; and $F$ is Faraday's constant. Because $\mathrm{NO}_{2}$ concentration varies with 
$\mathrm{O}_{2}$ concentration and temperature and it is usually lower than $30 \%$ of the total $\mathrm{NO}_{x}$ concentration, we calculated $\mathrm{CE}$ as the minimum by assuming all of the $\mathrm{NO}_{\mathrm{x}}$ were $\mathrm{NO}(z=2)$, in order to simplify the calculation and compare our results with the literature [9].

\subsection{Dependence of $\mathrm{NO}_{x}$ removal properties on $\mathrm{O}_{2}$ concentration}

The dependence of $\mathrm{NO}_{\mathrm{x}}$ removal properties of S1 (with the YSZ cover layer) and S2 (without the YSZ cover layer) on $\mathrm{O}_{2}$ concentration is shown in figures 2 and 3. The cells were polarized under $-2.5 \mathrm{~V}$ at $450{ }^{\circ} \mathrm{C}$ in 1000 ppm NO and different $\mathrm{O}_{2}$ concentrations with balance Ar. The concentration of $\mathrm{O}_{2}$ was varied from $0 \%$ to $8 \%$. The results reported by Hamamoto et al. [9] on an electrochemical cell with a YSZ cover layer, which has the same structure with S1, was also listed as a reference. The reference results, which were the best reported in the literature, were measured under the same polarization voltage $(-2.5)$ but at a higher temperature $\left(500^{\circ} \mathrm{C}\right)$. It was observed that without $\mathrm{O}_{2}$, both $\mathrm{S} 1$ and $\mathrm{S} 2$ could decompose $\mathrm{NO}_{x}$ with quite high activity and selectivity. After $\mathrm{O}_{2}$ was introduced, the activity of $\mathrm{S} 1$ sharply fell to less than $40 \%$ while the activity of S2 only slightly decreased from $100 \%$ to greater than $85 \%$; the current efficiencies of S1 and S2 both dropped to approximately 16\%, but the CE of S2 became increasingly higher than that of S1 with increasing $\mathrm{O}_{2}$ concentrations. Because S1 and S2 were prepared and tested under the same conditions, the difference in their performance could be ascribed to the presence of the YSZ cover layer, which strongly supported the great improvement in $\mathrm{NO}_{\mathrm{x}}$ removal properties by removing the YSZ cover layer. In comparing the results of this work with that of the reference, the $\mathrm{NO}_{\mathrm{x}}$ conversion rate of S1 was obviously lower than that of the reference cell. Because S1 should have the same structure as the reference cell, we assumed that the deviation might be caused by the difference of the raw material and some other preparation details, which have not yet been clearly identified. Other than the YSZ cover layer step, the cell S2 was prepared exactly in the same way as S1. Thus, if there was any negative effect on the structure brought by the preparation other than the YSZ cover 
layer, it should be equally present on $\mathrm{S} 2$. However, $\mathrm{S} 2$, showed a much higher $\mathrm{NO}_{\mathrm{x}}$ conversion rate than the reference cell. The current efficiency of S2 was slightly lower than that of the reference cell under low $\mathrm{O}_{2}$ concentrations, but became increasingly higher than the latter with increasing $\mathrm{O}_{2}$. Moreover, because the results of $\mathrm{S} 2$ were recorded at $50{ }^{\circ} \mathrm{C}$ lower than that in the reference [9], it indicated that by removing the YSZ cover layer, better performance could be achieved at a lower temperature, which further demonstrated that the modification of the structure was successful.

There was an unusual increase of the activity and selectivity of $\mathrm{S} 2$ in $8 \% \mathrm{O}_{2}$. The reason has not yet been identified, but it should not be ascribed to a measurement error because the result was reproducible. One possible reason for the promotion of $\mathrm{NO}_{x}$ conversion under higher $\mathrm{O}_{2}$ concentration was the larger ratio of $\mathrm{NO}_{2}$ to $\mathrm{NO}$ because $\mathrm{NO}_{2}$ was a stronger oxidant and proposed as an intermediate for $\mathrm{NO}$ reduction on the LSM|CGO electrode [24]. However, it was unclear why the promotion was only revealed on $\mathrm{S} 2$ when $8 \% \mathrm{O}_{2}$ was present.

\subsection{Dependence of $\mathrm{NO}_{\mathrm{x}}$ removal properties on temperature}

Figure 4 shows the performance of $\mathrm{S} 1$ and $\mathrm{S} 2$ for $\mathrm{NO}_{\mathrm{x}}$ decomposition at different temperatures under $2.5 \mathrm{~V}$ in $1000 \mathrm{ppm} \mathrm{NO}$ and $2 \% \mathrm{O}_{2}$ with balance Ar. It was observed that $\mathrm{S} 2$ gave a greatly higher activity for $\mathrm{NO}_{\mathrm{x}}$ decomposition than $\mathrm{S} 1$ over the entire temperature range and completely removed all the $\mathrm{NO}_{\mathrm{x}}$ at $475{ }^{\circ} \mathrm{C}$ and $500{ }^{\circ} \mathrm{C}$. Meanwhile, $\mathrm{S} 1$ decomposed less than $50 \% \mathrm{NO}_{\mathrm{x}}$ under the same conditions. The selectivity of S2 was also markedly higher than that of S1 at lower temperatures, but fell close to that of S1 at $475^{\circ} \mathrm{C}$ and slightly lower at $500^{\circ} \mathrm{C}$. S2 lost the advantage of selectivity over S1 at high temperature, as it was approaching the limit for $\mathrm{NO}_{\mathrm{x}}$ conversion. At $450{ }^{\circ} \mathrm{C}$, the $\mathrm{NO}_{\mathrm{x}}$ conversion of $\mathrm{S} 2$ achieved $92 \%$, so with additional temperature increases, there was little room for further increases in $\mathrm{NO}_{\mathrm{x}}$ conversion. At $475{ }^{\circ} \mathrm{C}$, S2 completely decomposed all the $\mathrm{NO}_{\mathrm{x}}$ in the system. The current for reducing $\mathrm{NO}\left(\mathrm{I}_{\mathrm{NO}}\right)$ had reached the maximum and could not increase further at elevated temperatures. Under these conditions, 
the increased activity of the system at high temperatures resulted in increased $\mathrm{O}_{2}$ reduction rather than $\mathrm{NO}_{x}$ reduction. As a result, the decline in selectivity of $\mathrm{S} 2$ was magnified at high temperatures. This result indicated that $\mathbf{S} 2$ might have the potential to give a higher selectivity at high temperature when a larger amount of $\mathrm{NO}_{x}$ is presented. It is noteworthy that $\mathrm{S} 2$ showed a similar $\mathrm{NO}_{\mathrm{x}}$ conversion (8.5\% lower) and a far greater $\mathrm{CE}\left(48.5 \%\right.$ higher) at as low as $425^{\circ} \mathrm{C}$ compared with the reference cell at $500{ }^{\circ} \mathrm{C}$ [9].

\subsection{Dependence of $\mathrm{NO}_{x}$ removal properties on polarization voltage}

Figure 5 shows the $\mathrm{NO}_{\mathrm{x}}$ removal properties at various voltages at $450{ }^{\circ} \mathrm{C}$ in $1000 \mathrm{ppm} \mathrm{NO}$ and $2 \% \mathrm{O}_{2}$ with balance Ar. S2 reduced near $50 \% \mathrm{NO}_{x}$ under voltage as low as $-1.5 \mathrm{~V}$ and completely removed all the $\mathrm{NO}_{\mathrm{x}}$ from $-3.5 \mathrm{~V}$ to $-4.5 \mathrm{~V}$, while the $\mathrm{NO}_{\mathrm{x}}$ conversion of $\mathrm{S} 1$ was below $50 \%$ over the entire voltage range. The selectivity of S2 was increasingly higher than that of S1 with voltage decreasing below $-2.5 \mathrm{~V}$. Above -2.5 $\mathrm{V}$, the $\mathrm{CE}$ of $\mathrm{S} 2$ decreased to values near that of $\mathrm{S} 1$. In the case of $\mathrm{S} 2$, the $\mathrm{NO}_{\mathrm{x}}$ conversion increased rather linearly by increasing the voltage up to $-2.5 \mathrm{~V}$, while eventually reached a steady state above -3.5 V which behavior could be an evidence of a diffusion controlled process taking place. Specifically, in the range of $-2.5 \mathrm{~V}$ and $-3.5 \mathrm{~V}$, the process could be likely a mixed controlled behavior, limited both by the mass transfer of $\mathrm{NO}_{x}$ species towards the electrode or product species from the electrode, and by charge transfer or surface adsorption/desorption processes depended on the change of voltage. However, it is needed to point out that the application of voltage higher than $-3.5 \mathrm{~V}$ resulted in a $100 \%$ conversion of $\mathrm{NO}_{x}$ species present in the gas mixture. Therefore, even though the absolute value of the applied voltage increased, the $\mathrm{NO}_{\mathrm{x}}$ conversion could not further be increased, since $\mathrm{NO}_{\mathrm{x}}$ species in the system have been already completely reduced by S2. For sample S1, with YSZ cover layer, it seems not to be a simple diffusion controlled behavior, although the diffusion of $\mathrm{NO}_{x}$ species to the electrode should be seriously impeded by the YSZ cover layer. One possible explanation is that not only the 
diffusion of $\mathrm{NO}_{x}$ species was impeded, but also the other processes related with the electrochemical reduction of $\mathrm{NO}_{x}$ were affected by the existence of YSZ cover layer.

\subsection{Selectivity towards $\mathrm{N}_{2}$ formation}

On both $\mathrm{S} 1$ and $\mathrm{S} 2$, the amount of $\mathrm{N}_{2}$ formation measured by mass spectrometer was quite close to that calculated from $\mathrm{NO}_{x}$ decomposition (see equation 4). The $\mathrm{N}_{2}$ selectivity ( $\eta$, see equation 3 ) was approximately $90 \%$ under all the test conditions. Taking into account the $\mathrm{N}_{2}$ formation calculated for sample $\mathrm{S} 2$ at different $\mathrm{O}_{2}$ concentrations as an example (table 1), it was found that the selectivity towards $\mathrm{N}_{2}$ formation was as high as $91.5 \%$ without $\mathrm{O}_{2}$; While in presence of $\mathrm{O}_{2}$, the $\mathrm{N}_{2}$ selectivity decreased slightly below $90 \%$. Besides, no $\mathrm{N}_{2} \mathrm{O}$ was detected by mass spectrometry in all the tests. Therefore, it is concluded that both S1 and S2 have high selectivity towards $\mathrm{N}_{2}$ formation.

In summary, compared with the sample with the YSZ cover layer, the sample without a YSZ cover layer gave much higher activity for $\mathrm{NO}_{\mathrm{x}}$ decomposition under all the tested voltages, temperatures and $\mathrm{O}_{2}$ concentrations, providing better selectivity at low voltage $(-1.5 \mathrm{~V}$ to $-2.75 \mathrm{~V})$, intermediate temperature $\left(375^{\circ} \mathrm{C}\right.$ to $450{ }^{\circ} \mathrm{C}$ ) and high $\mathrm{O}_{2}$ concentrations ( $4 \%$ to $8 \%$ ). Therefore, by removing the YSZ cover layer, the $\mathrm{NO}_{\mathrm{x}}$ removal properties of the electrochemical cell with an adsorption layer could be dramatically enhanced under harsh conditions.

\section{Discussions}

\subsection{Reasons for activity enhancement}

According to systematic research $[8,12-15]$ on the NiO|YSZ catalytic layer by Bredikhin and colleagues, it is believed that there are two reaction sites for $\mathrm{NO}$ and $\mathrm{O}_{2}$ molecules in the catalytic layer. As schematically shown in figure 6, one is the F-center near the three phase boundaries of YSZ|Pt|gas or $\mathrm{YSZ} \mid \mathrm{Ni}$ |gas, which is dominated by $\mathrm{O}_{2}$ reduction in $\mathrm{O}_{2}$-rich environment. The other is the nano-sized $\mathrm{Ni}$ 
particle generated by reducing NiO under cell operation, which can preferably adsorb and decompose $\mathrm{NO}$ in the presence of $\mathrm{O}_{2}$ [16-19], thus providing an effective reaction site for the selective reduction of $\mathrm{NO}_{\mathrm{x}}$. The reaction mechanism can be modeled by the following equations.

For $\mathrm{O}_{2}$ reduction:

For NO reduction:

(6)

In this study, one of the major reasons for the enhancement of $\mathrm{NO}_{\mathrm{x}}$ reduction activity by removing the YSZ cover layer was thought to be the increase in active reaction sites for $\mathrm{NO}_{\mathrm{x}}$ reduction. This assumption was corroborated by the microstructure observation and EDS analysis results of the NiO|YSZ layer.

Figure 7 shows the microstructure images for the cathodes of S1 and S2 before and after measurement. It can be clearly seen that there were nano-particles and nano-pores generated in the NiO|YSZ catalytic layer after measurement, which was due to the reduction of $\mathrm{NiO}$ to $\mathrm{Ni}$ by the cell operation. More importantly,_it was found that there was a large amount of nano-Ni particles left on S1 compared to S2, which was confirmed by composition analysis by EDS in figure 8. It was previously demonstrated that because the oxidation of $\mathrm{Ni}$ by $\mathrm{O}_{2}$ started at $350{ }^{\circ} \mathrm{C}$ [25], most of the unconsumed $\mathrm{Ni}$ would be reoxidized by $\mathrm{O}_{2}$ during the cooling period without the protection of applied voltage [26]. In this work, both $\mathrm{S} 1$ and $\mathrm{S} 2$ were held in $2 \% \mathrm{O}_{2}$ at $500^{\circ} \mathrm{C}$ for approximately 10 hours before cooling down. Therefore, 
the Ni particles should be almost fully re-oxidized unless they cannot be reached by $\mathrm{O}_{2}$. Significantly more residual $\mathrm{Ni}$ in the catalytic layer of $\mathrm{S} 1$ indicated that the gas path to the nano-Ni grains was severely impeded or even blocked compared with that of S2, which led to a large loss of active sites for $\mathrm{NO}_{\mathrm{x}}$ reduction. By removing the $\mathrm{YSZ}$ cover layer, a significant number of reaction sites for $\mathrm{NO}_{\mathrm{x}}$ reduction could be released, greatly enhancing the $\mathrm{NO}_{\mathrm{x}}$ reduction activity of $\mathrm{S} 2$.

\subsection{Reasons for selectivity increase}

In addition to the activity enhancement for $\mathrm{NO}_{x}$ reduction, the $\mathrm{O}_{2}$ reduction also increased after removing the YSZ cover layer, because the suppression of $\mathrm{O}_{2}$ adsorption and decomposition on the open surface of the catalytic layer by the YSZ layer was lost as well. On an electrochemical cell without an adsorption layer, omitting the YSZ cover layer resulted in a lower selectivity for $\mathrm{NO}_{\mathrm{x}}$ reduction. However, in the case with an adsorption layer, the cell without a YSZ cover layer showed much better selectivity under harsh conditions while simultaneously maintaining a high activity.

The difference was most likely due to the introduction of the adsorption layer. The adsorption layer on the electrochemical cell is made of an NSR catalyst $\left(\mathrm{Pt}-\mathrm{K}-\mathrm{Al}_{2} \mathrm{O}_{3}\right)$ but is not used in the same way as an NSR catalyst [22]. The NSR catalyst is operated via cyclic switches between lean and rich conditions. $\mathrm{NO}_{\mathrm{x}}$ gases are trapped and stored in the form of nitrate under lean condition. The nitrate is then induced to decompose by the switch to rich condition. The released $\mathrm{NO}_{x}$ species are reduced near the trapping sites by the reducing agents. While on the electrochemical cell, there is no gas switch to induce the decomposition of nitrate. The reduction of $\mathrm{NO}_{\mathrm{x}}$ is not accomplished near the trapping sites in the adsorption layer, but rather inside the NiO/YSZ layer, which means the stored $\mathrm{NO}_{\mathrm{x}}$ species has to be released by the decomposition of the nitrate $\left(\mathrm{KNO}_{3}\right.$ in this case) and then diffuse through the adsorption layer to the reaction sites in the NiO|YSZ layer. There are then two steps that likely become rather difficult by depositing an additional YSZ cover layer on the electrochemical cell. 
One step is the diffusion of the released $\mathrm{NO}_{x}$ species from the storage sites to the reaction sites. With a YSZ cover layer in between, diffusion is severely impeded or even blocked, which has been demonstrated above. The other step is the decomposition of nitrate on the alkali component $\left(\mathrm{KNO}_{3}\right)$, which is the pre-step for $\mathrm{NOx}$ release and, more importantly, regeneration of the $\mathrm{NO}_{\mathrm{x}}$ storage sites to trap $\mathrm{NO}_{\mathrm{x}}$ continuously. Thus, this step is vital to the overall efficiency of the adsorption layer. Because of missing the strong driving force from gas switch, the decomposition of $\mathrm{KNO}_{3}$ on the electrochemical cell with the YSZ cover layer can only be driven by the concentration gradient of $\mathrm{NO}_{\mathrm{x}}$ species along the adsorption layer, which should be comparatively weak and insufficient. Consequentially, the adsorption layer was incapable of trapping $\mathrm{NO}_{x}$ as effectively as possible.

Correspondingly, by removing the YSZ cover layer the aforementioned two steps can be significantly affected in a positive way. Firstly, the diffusion of $\mathrm{NO}_{x}$ species from the trapping sites to the reaction sites could becomes unobstructed, which would in turn benefit the adsorption and desorption of $\mathrm{NO}_{\mathrm{x}}$ species inside the adsorption layer. Secondly, by removing the $\mathrm{YSZ}$ cover layer, the $\mathrm{KNO}_{3}$ on the trapping sites near the interface between the adsorption layer and the Pt layer was able to be directly decomposed by the negative polarization applied during the operation, which was essentially impossible with the presence of YSZ cover layer because it covered nearly the whole interface between these two layers. According to the research on molten potassium nitrate $\left(\mathrm{KNO}_{3}\right)$, the decomposition of $\mathrm{KNO}_{3}$ starts at a potential of $-0.65 \mathrm{~V}$ (vs. $\mathrm{Ag}\left|\mathrm{Ag}^{+}\right| \mathrm{NO}_{3}{ }^{-}$) on a Pt cathode at $340{ }^{\circ} \mathrm{C}$ [27]. Because the electrochemical cell was polarized under the voltage from $-1.5 \mathrm{~V}$ to $-4.5 \mathrm{~V}$ and operated above the melting point of $\mathrm{KNO}_{3}$, after removing the $\mathrm{YSZ}$ cover layer, the decomposition of $\mathrm{KNO}_{3}$ on the interface should be easily achieved while the electrochemical cell is running. As a result, the trapped $\mathrm{NO}_{\mathrm{x}}$ species could be effectively released and reduced on the reaction sites nearby. The trapping sites of the adsorption layer were able to be quickly regenerated near the interfacial area. 
Figure 9 shows the microstructure pictures and EDS analysis results for the interface of the adsorption layer and cathode of S1 and S2 after testing. On S2, many tiny Pt particles accumulated around the Pt surface bared in the adsorption layer, and a thin Pt layer deposited on the open surface of the YSZ nearby. On S1, a similar phenomenon was only observed on the Pt surface exposed to the adsorption layer through a few narrow gaps of the dense YSZ layer. It was reported that in the molten $\mathrm{KNO}_{3}$ with the cathodic potential increasing to greater than $-1.5 \mathrm{~V}$, Pt was extensively oxidized to Pt oxide by the potassium peroxide formed through the accumulation of $\mathrm{O}^{2-}$ under continuous $\mathrm{KNO}_{3}$ decomposition [27]. On a solid state fuel cell, it was reported that $\mathrm{Pt}$ could migrate via $\mathrm{PtO}_{2}$ gas vaporized from the Pt current collector and be deposited around the TPBs (three phase boundaries) because the volatility of $\mathrm{PtO}_{2}$ was comparatively higher among the Pt species $[28,29]$. Therefore, we concluded that the Pt particles accumulation and Pt layer deposition on our cells were caused by redistribution of Pt from the Pt layer through a mechanism of oxidation of Pt by the potassium peroxide, diffusion of gas phase Pt oxide and subsequent decomposition or reduction of Pt oxide to Pt under negative polarization. It must be noted that the oxidation of Pt was not likely due to the reaction between $\mathrm{Pt}$ and $\mathrm{O}_{2}$ or $\mathrm{NO}$ because in that case, the oxidation should be much weaker and should only be able to result in an extremely small amount of Pt migration. The intensive redistribution of Pt provided an evidence for the decomposition of $\mathrm{KNO}_{3}$ by polarization at the interface of the Pt layer and adsorption layer. However, such benefits for $\mathrm{KNO}_{3}$ decomposition were negligible on the cell with the YSZ cover layer because the electronic insulated layer extensively broke the connection between the Pt layer and adsorption layer.

Moreover, it should be noted that by removing the YSZ cover, there was a possibility for the $\mathrm{KNO}_{3}$ to be reduced directly to $\mathrm{N}_{2}$ over the potassium trapping sites adjacent to Pt|YSZ|gas TPBs (three phase boundaries) under negative polarization. The reduction of $\mathrm{NO}_{\mathrm{x}}$ through this short reaction path, as shown in equation 9, should be much more efficient than through a long path of $\mathrm{KNO}_{3}$ decomposition, $\mathrm{NO}_{x}$ diffusion to nano-Ni grains and finally $\mathrm{NO}_{x}$ reduction to $\mathrm{N}_{2}$ over the Ni grains. Thus, the Pt|YSZ|gas 
TPBs could also work as the selective reaction sites for $\mathrm{NO}_{x}$ reduction rather than only being dominated by $\mathrm{O}_{2}$ reduction if they remained connected with the adsorption layer. This effect might be one of the reasons for the selectivity improvement by removing the YSZ cover layer.

In summary, these two steps, diffusion of $\mathrm{NO}_{\mathrm{x}}$ species and regeneration of $\mathrm{NO}_{\mathrm{x}}$ trapping sites, which might limit the performance of the NSR adsorption layer on the electrochemical cell with a YSZ cover layer, were distinctly improved by removing the YSZ cover layer. These improvements gave rise to a much more efficient adsorption layer for $\mathrm{NO}_{\mathrm{x}}$ trapping and smoother transport for the $\mathrm{NO}_{\mathrm{x}}$ species to the reaction sites. Additionally, a short reaction path of direct reduction of $\mathrm{KNO}_{3}$ to $\mathrm{N}_{2}$ might be created at the interface of the Pt layer and adsorption layer. Combined, all of these positive effects could greatly promote the $\mathrm{NO}_{x}$ reduction and make it more pronounced than the increase of $\mathrm{O}_{2}$ reduction. As a result, selectivity was not decreased, but rather increased by removing the YSZ cover layer.

\section{Conclusions}

By the optimization of removing the $\mathrm{YSZ}$ cover layer, the $\mathrm{NO}_{\mathrm{x}}$ removal properties of an electrochemical cell with an adsorption layer was dramatically enhanced, especially under conditions of low voltage, intermediate temperature and high $\mathrm{O}_{2}$ concentration.

The large increase of $\mathrm{NO}_{x}$ decomposition activity was due to the extensive release of the reaction sites for $\mathrm{NO}_{\mathrm{x}}$ reduction by removing the $\mathrm{YSZ}$ cover layer. The improvement of selectivity for $\mathrm{NO}_{\mathrm{x}}$ reduction in spite of the increase of $\mathrm{O}_{2}$ reduction was attributed to the interaction of the adsorption layer with the Pt layer and the catalytic layer strongly promoting the reduction of $\mathrm{NO}_{\mathrm{x}}$, which was specified as the following: 
1) The diffusion of $\mathrm{NO}_{x}$ species from the adsorption layer into the reaction sites on the $\mathrm{NiO}$ |YSZ catalytic layer was greatly enhanced after optimization.

2) The trapping sites of the adsorption layer in the interfacial area of the Pt layer and adsorption layer were quickly regenerated by the decomposition of nitrite under negative potential.

3) The direct reduction of $\mathrm{KNO}_{3}$ to $\mathrm{N}_{2}$ could be realized over the Pt|YSZ | gas TPBs adjacent to the $\mathrm{NO}_{x}$ storage sites of the adsorption layer.

Through the structure optimization of removing the YSZ cover layer, an electrochemical cell with an adsorption layer was able to give good performance under harsh conditions, may providing a promising solution for $\mathrm{NO}_{\mathrm{x}}$ emission control.

\section{Acknowledgements}

The author would like to acknowledge the financial support of the Danish Strategic Research Council under contract no. 09-065186. We are grateful to our colleagues at the Fuel Cell and Solid State Chemistry Division, Ris $\varnothing$-DTU for help and discussion.

\section{References}

1. Burch R, Breen J and Meunier F (2002) Appl Catal B:Environ 39:283-303

2. Krivoshto IN, Richards JR, Albertson TE and Derlet RW (2008) J Am Board Fam Med 21:55-62

3. Lerdau MT, Munger JW and Jacob DJ (2000) Science 289(5488):2291-2293

4. Finlayson-Pitts BJ, Pitts JN Jr (1997) Science 276(5315):1045-1051

5. www.dieselnet.com/standards Accessed 08 Feb 2012

6. Garin F (2001) Appl Catal A: Gen 222:183-219

7. Hansen KK (2010) Appl Catal B: Environ 100:427-432

8. Bredikhin S, Hamamoto K, Fujishiro Y and Awano M (2009) Ionics 15:285-299 
9. Hamamoto K, Fujishiro Y and Awano M (2008) J Electrochem Soc 155:E109-E111

10. Hamamoto K (2011) J Ceram Soc Jpn 119:89-92

11. Hamamoto K, Suzuki T, Fujishiro Y and Awano M (2011) J Electrochem Soc 158(8):B1050-B1053

12. Hamamoto K, Hiramatsu T, Shiono O, Katayama S, Fujishiro Y, Bredikhin S, Awano M (2004) J Ceram Soc Jpn Supplement 112(5):S1071-S1074

13. Awano M, Bredikhin S, Aronin A, Abrosimova G, Katayama S, Hiramatsu T (2004) Solid State Ionics 175:605-608

14. Hamamoto K, Fujishiro Y and Awano M (2006) J Electrochem Soc 153(11):D167-D170

15. Aronin A, Abrosimova G, Bredikhin S, Matsuda K, Maeda K, Awano M (2005) J Am Ceram Soc 88(5):1180-1185

16. Brown WA, Kose R and King DA (1998) Chem Rev 98:797-832

17. Karmazyn AD, Fiorin V and King DA (2003) Sur Sci 547:184-192

18. Odörfer G, Jaeger R , Illing G, Kuhlenbeck H and Freund HJ (1990) Sur Sci 233:44-58

19. Miura K, Nakagawa H, Kitaura R, Satoh T (2001) Chem Eng Sci 56:1623-1629

20. Bredikhin S, Maeda K, Awano M (2001) Solid State lonics 144:1-9

21. Bredikhin S, Maeda K, Awano M (2002) Solid State lonics 152-153:727-733

22. Epling WS, Campbell LE, Yezerets A, Currier NW, Parks JE (2004) Catal Rev 46(2):163-245

23. Werchmeister RML, Hansen KK and Mogensen M (2010) Mater Res Bull 45(1):1554-1561

24. Werchmeister RM, Hansen KK and Mogensen M (2010) J Electrochem Soc 157(5):P35-P42

25. Hamamoto K, Fujishiro Y and Awano M (2007) J Electrochem Soc 154(9):F172-F175

26. Bredikhin S, Abrosimova G, Aronin A and Awano M (2006) lonics 12:33-39

27. Shibata S and Sumino MP (1975) Electrochimica Acta 20:871-876

28. Simmer SP, Anderson MD, Pederson LP and Stevenson JW (2005) J Electrochem Soc 152:A1851A1859 
29. Xiong Y, Yamaji K, Kishimoto H, Brito ME, Horita T, Yokokawa H, Electrochem Solid-State Lett (2009) 12(3):B31-B33 
Table 1 Selectivity towards $\mathrm{N}_{2}$ formation on sample S2, without YSZ cover layer, at various $\mathrm{O}_{2}$ concentrations and $1000 \mathrm{ppm}$ NO with balance Ar under $-2.5 \mathrm{~V}$ at $450{ }^{\circ} \mathrm{C}$

\begin{tabular}{cccc}
\hline $\begin{array}{c}\mathrm{O}_{2} \text { concentrations } \\
/ \%\end{array}$ & $\begin{array}{c}\mathrm{N}_{2} \text { formation }\left(\Delta \mathrm{N}_{2}\right) \\
/ \mathrm{ppm}\end{array}$ & $\begin{array}{c}\mathrm{NO}_{\mathrm{x}} \text { decomposition }\left(\Delta \mathrm{NO}_{\mathrm{x}}\right) \\
/ \mathrm{ppm}\end{array}$ & $\begin{array}{c}\mathrm{N}_{2} \text { selectivity }(\eta)^{\mathrm{a}} \\
/ \%\end{array}$ \\
\hline 0 & 455 & 995 & 91.5 \\
1 & 403 & 919 & 87.7 \\
2 & 396 & 899 & 88.1 \\
4 & 388 & 869 & 89.3 \\
8 & 411 & 939 & 87.5 \\
\hline
\end{tabular}

\footnotetext{
${ }^{\mathrm{a}} \mathrm{N}_{2}$ selectivity $(\eta)$ is calculated as in equation 3, according to the decomposition reaction of $\mathrm{NO}_{\mathrm{x}}$ to $\mathrm{N}_{2}$ as showing in equation 4:
}

(3)

(4) 
Figure $1 \mathrm{~A}$ sketch of the electrochemical cell with a multilayered cathode and a $\mathrm{NO}_{\mathrm{x}}$ adsorption layer for removal of $\mathrm{NO}_{x}[9]$.

Figure 2 Activity of different cells toward $\mathrm{NO}_{x}$ decomposition at various $\mathrm{O}_{2}$ concentrations and $1000 \mathrm{ppm}$ NO with balance Ar under $-2.5 \mathrm{~V}$ at $450^{\circ} \mathrm{C}$. (S1: with a YSZ cover layer; S2: without a YSZ cover layer)

Figure 3 Selectivity of different cells toward $\mathrm{NO}_{x}$ decomposition at various $\mathrm{O}_{2}$ concentrations and 1000 ppm NO with balance Ar under $-2.5 \mathrm{~V}$ at $450^{\circ} \mathrm{C}$. (S1: with a YSZ cover layer; S2: without a YSZ cover layer) Figure $4 \mathrm{NO}_{\mathrm{x}}$ removal properties of different cells as a function of temperature under $-2.5 \mathrm{~V}$ in $1000 \mathrm{ppm}$ $\mathrm{NO}$ and $2 \% \mathrm{O}_{2}$ with balance Ar. (S1: with a YSZ cover layer; S2: without a YSZ cover layer)

Figure $5 \mathrm{NO}_{\mathrm{x}}$ removal properties of different cells as a function of voltage at $450{ }^{\circ} \mathrm{C}$ in $1000 \mathrm{ppm}$ NO and $2 \% \mathrm{O}_{2}$ with balance Ar. (S1: with a YSZ cover layer; S2: without a YSZ cover layer)

Figure 6 Schematic representation of the reaction sites for NO and oxygen gases in the catalytic layer [8, $12-15]$

Figure 7 Microstructure images for the cathodes of different cells before and after testing. The images show: A: S1 cathode before testing, B: S1 cathode after testing, C: S2 cathode before testing, D: S2 cathode after testing (S1: with a YSZ cover layer; S2: without a YSZ cover layer)

Figure 8 Microstructure image and EDS results for the NiO|YSZ catalytic layer of the cell (S1) with a YSZ cover layer after testing.

Figure 9 Microstructure images and EDS results for the Pt layer|adsorption layer interfaces of different cells after testing. (S1: with a YSZ cover layer; S2: without a YSZ cover layer) 
Figure 1

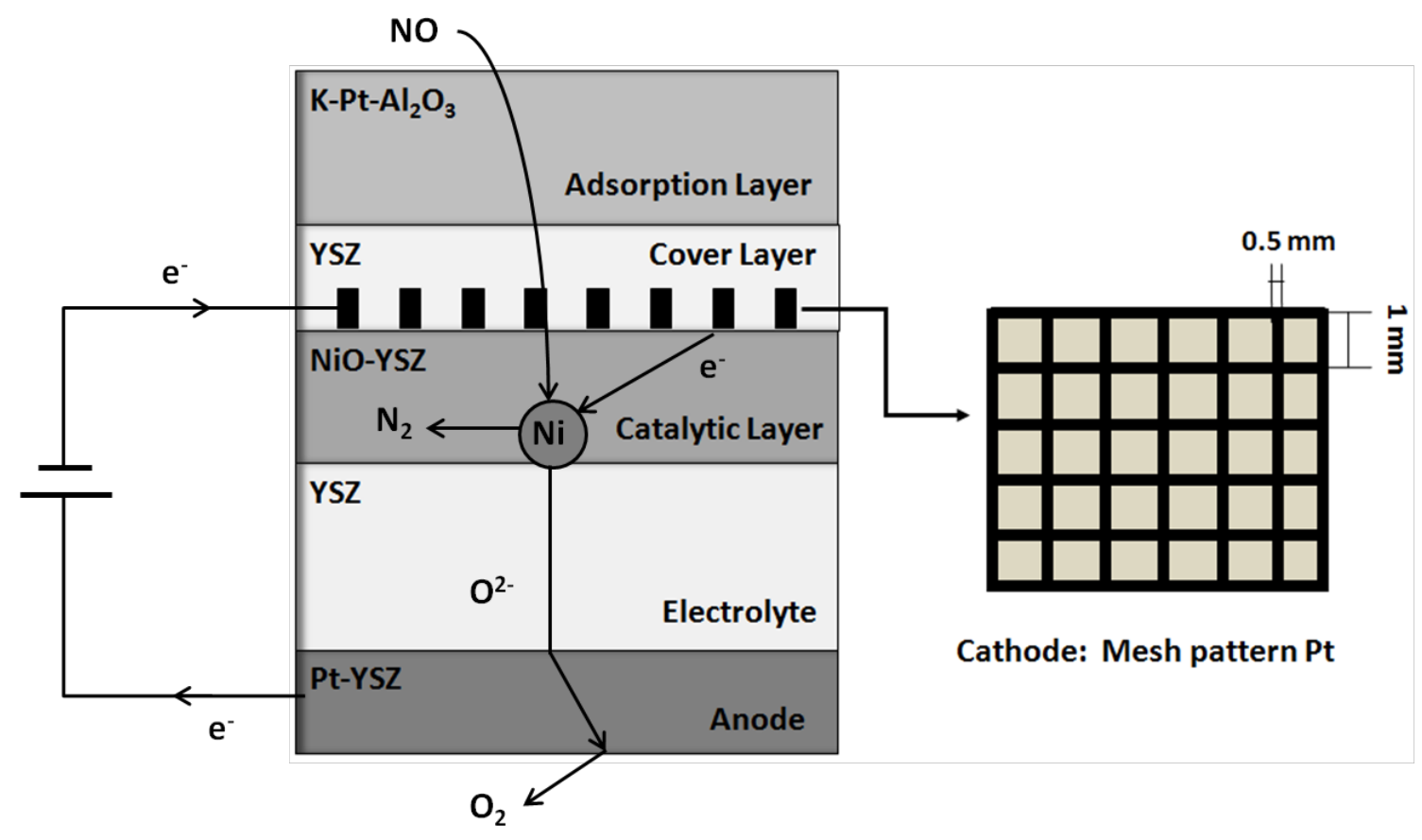


Figure 2

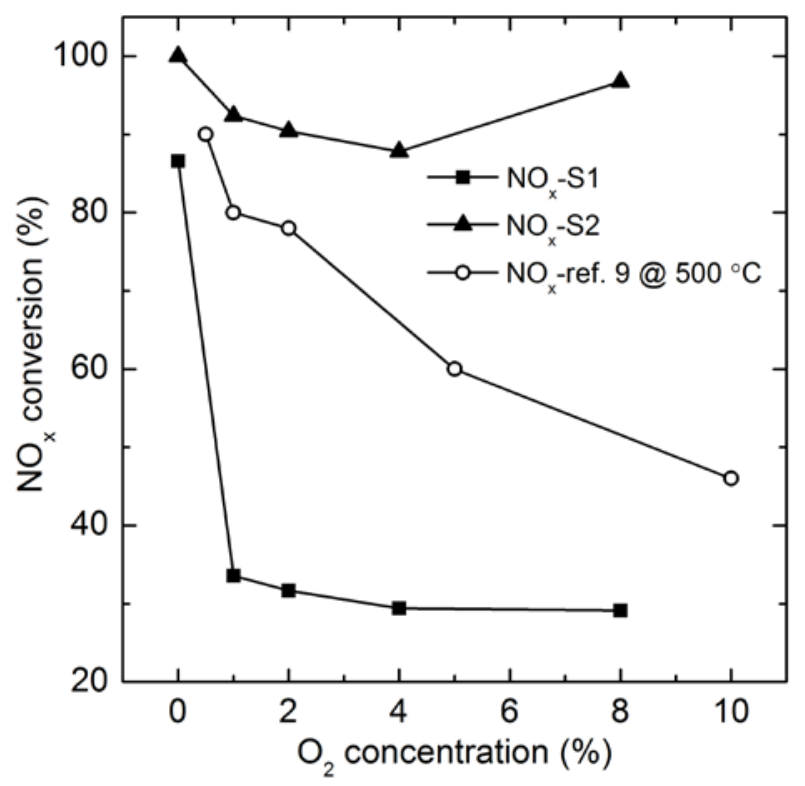


Figure 3

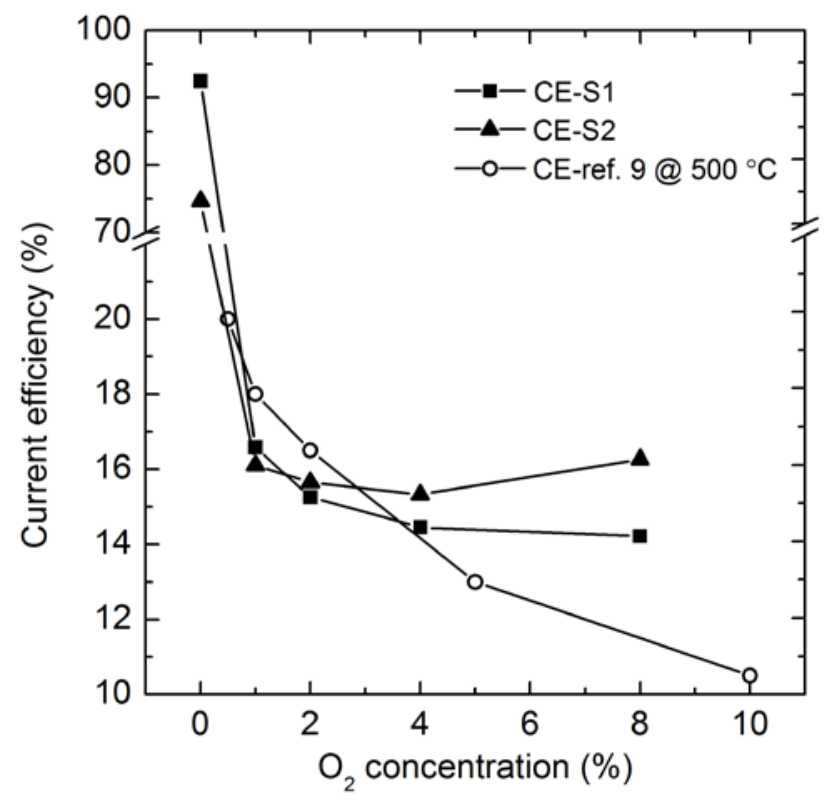


Figure 4

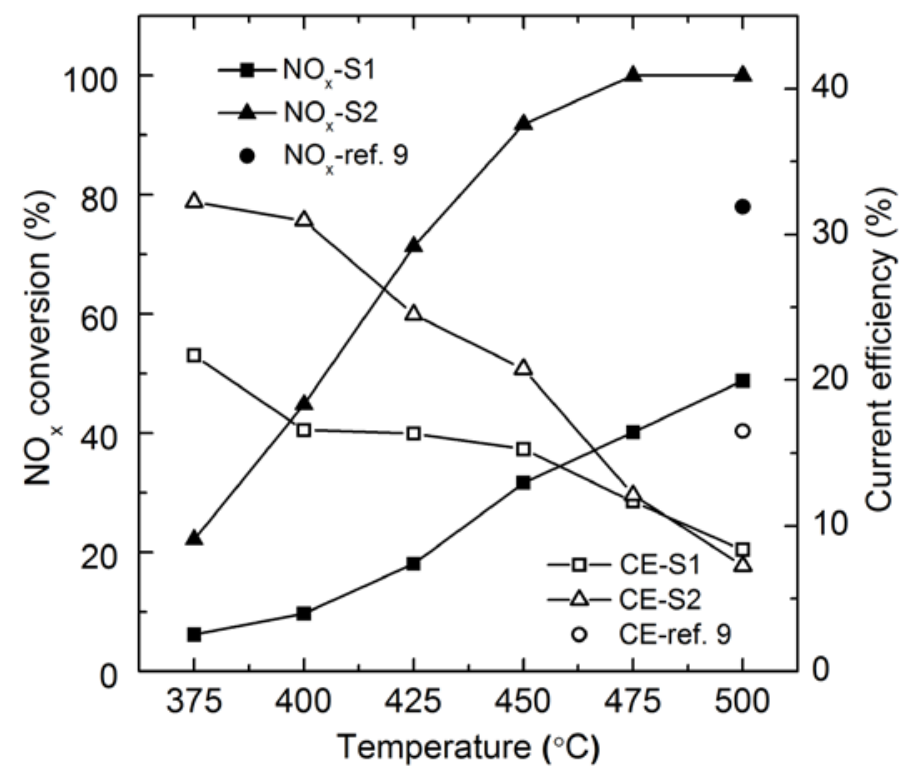


Figure 5

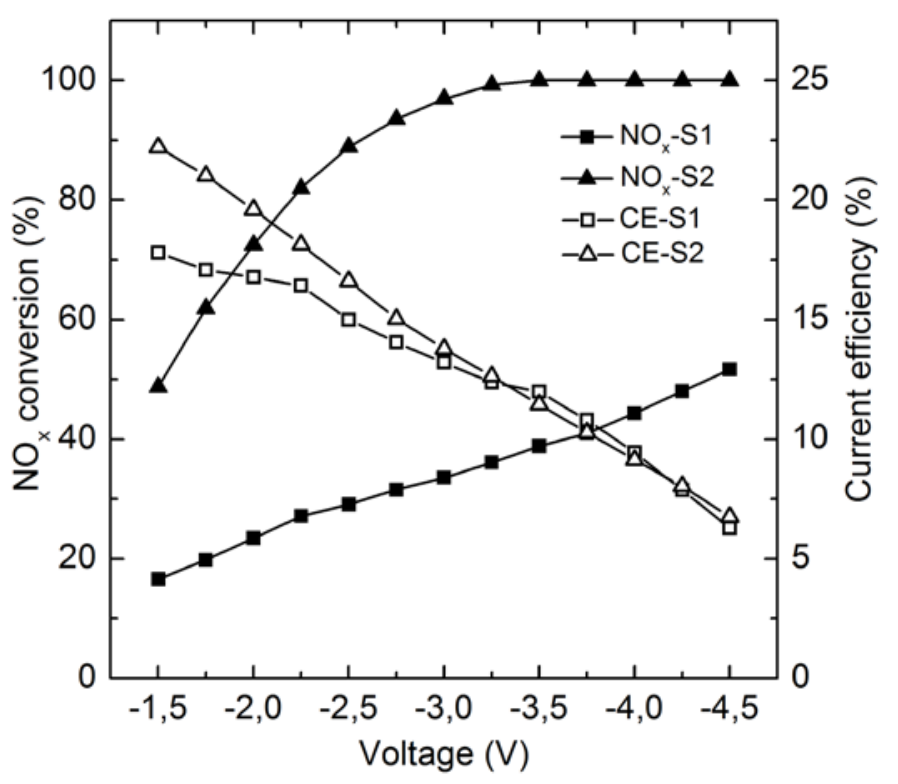


Figure 6

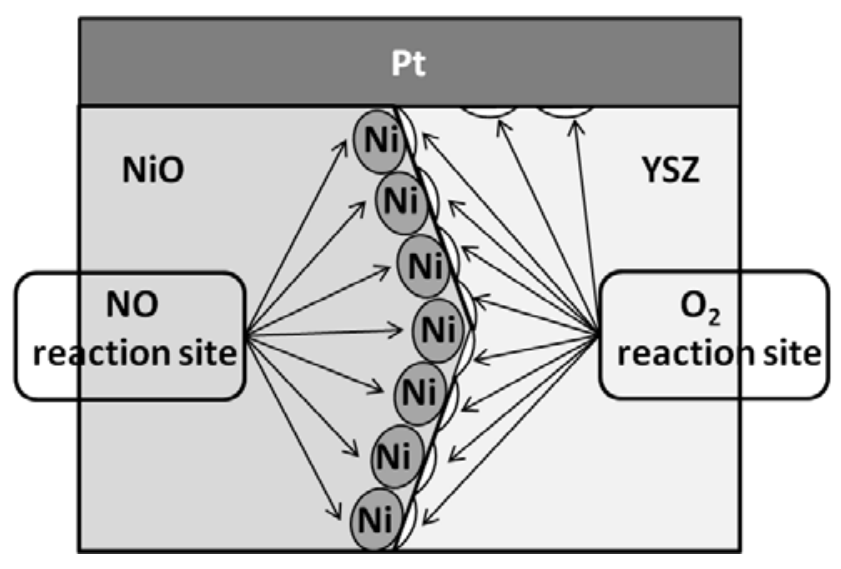


Figure 7
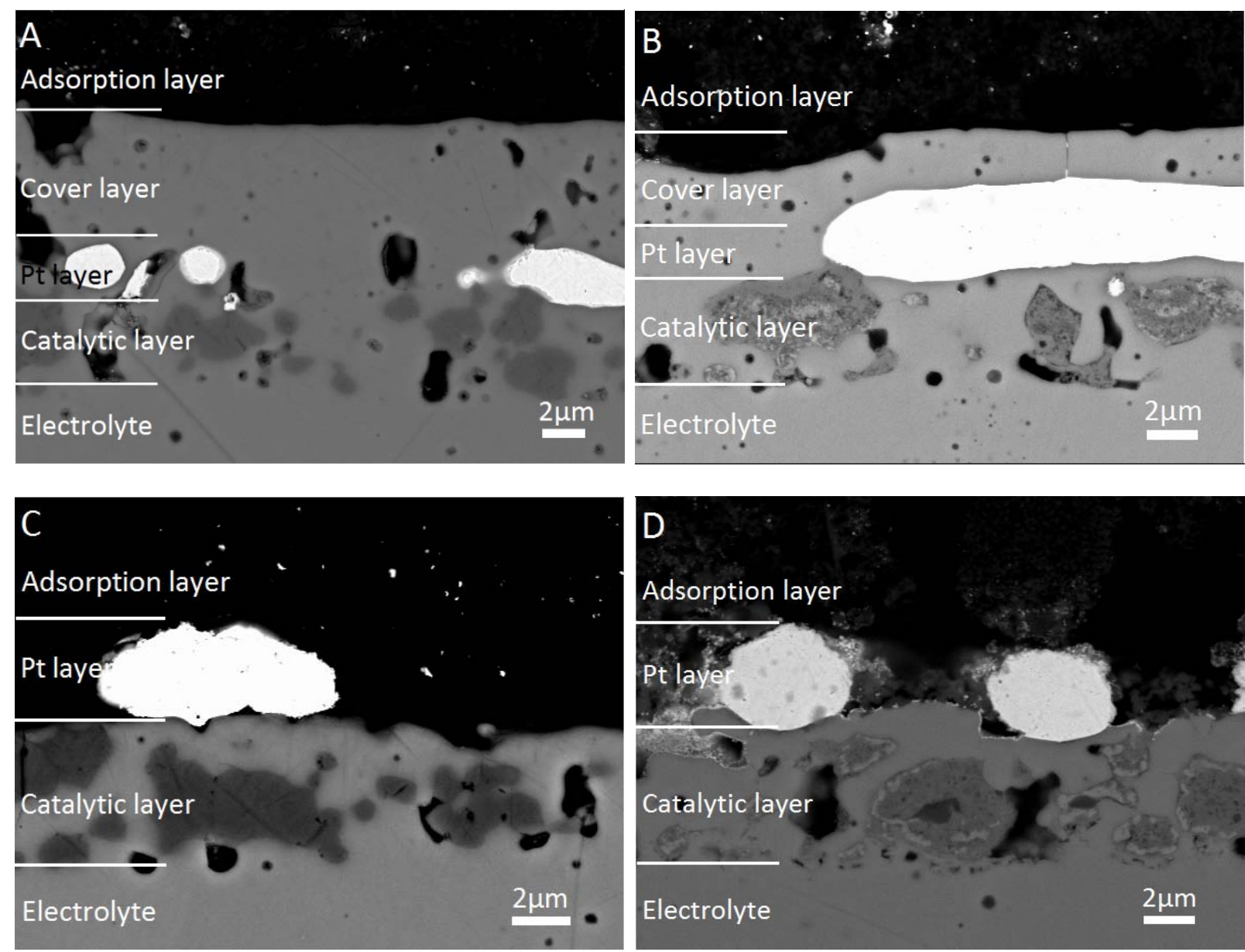
Figure 8

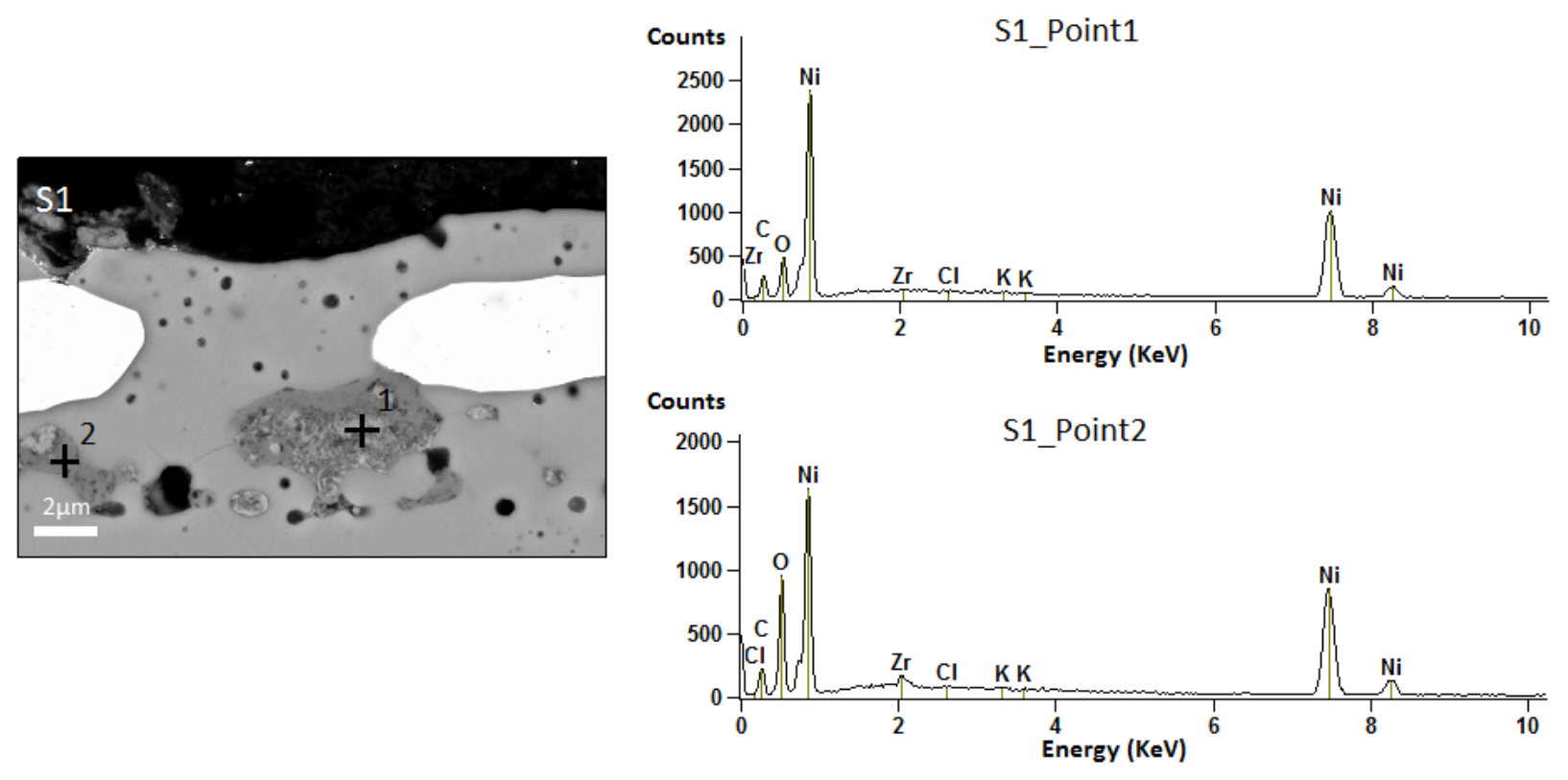


Figure 9
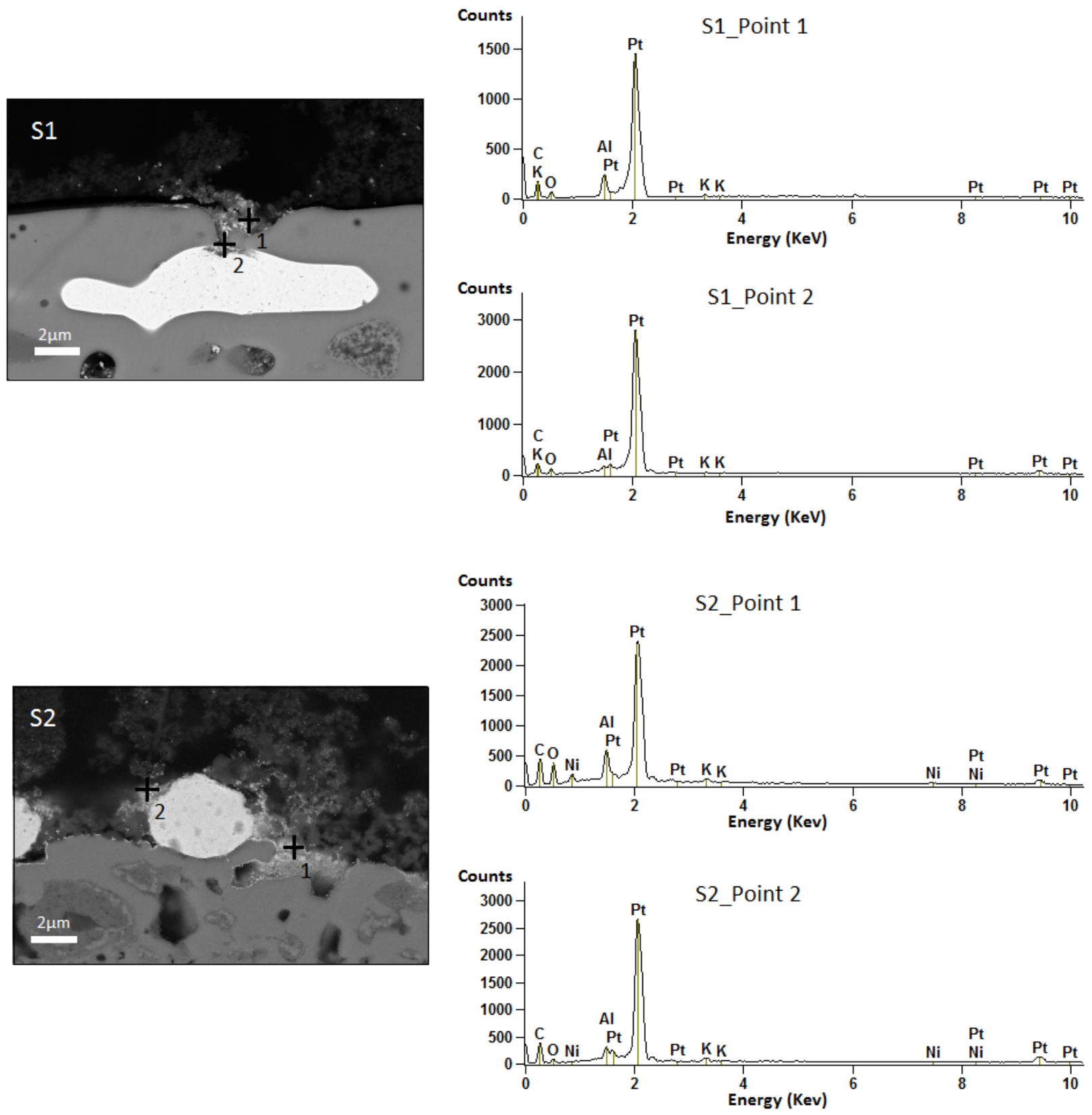